\title{
INTERNATIONAL HUMAN RIGHTS, INTERNATIONAL HUMANITARIAN LAW, AND ENVIRONMENTAL SECURITY: CAN THE INTERNATIONAL CRIMINAL COURT BRIDGE THE GAPS?
}

\author{
Mark A. Drumbl
}

I. INTRODUCTION ........................ 305

II. OVERVIEW OF THE ENVIRONMENTAL CONSEQUENCES OF ARMED CONFLICT . . . . . . . . . . . . . . . . . . . . 307

III. THE ICC AND ENVIRONMENTAL PROTECTION:

THE LANGUAGE OF THE RoME STATUTE $\ldots \ldots \ldots \ldots \ldots .310$

A. The Physical Act: Widespread, Long-term and Severe

Damage ........................ 315

B. Exculpatory Effects of Military Advantage ......... 319

C. The Mental Element: Strict Intentionality ......... 321

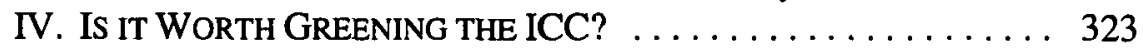

A. Environmental Concerns Lost in the Shuffle ....... 326

B. Low Environmental Expertise of the Judges and

Prosecutors ... . . . . . . . . . . . . . . . . . . . . 327

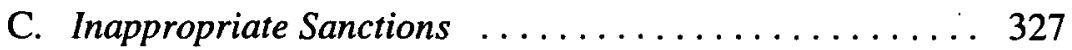

D. Limited Scope of Judicial Interpretation . . . . . . . . . 329

E. No Room for Negligence or Recklessness .... . . . . . 330

V. Punitive Sanction, Proactive Protection, or

ENVIRONMENTAL JUSTICE $? \ldots \ldots \ldots \ldots \ldots \ldots \ldots \ldots \ldots \ldots$

VI. Conclusion $\ldots \ldots \ldots \ldots \ldots \ldots \ldots \ldots \ldots \ldots \ldots \ldots \ldots \ldots$

\section{INTRODUCTION}

Human rights law has evolved considerably over the past half-century. Much of this evolution has occurred at the international level. Evolution can, of course, consist of growth and expansion, or decline and regression. For the

* Assistant Professor, School of Law, University of Arkansas at Little Rock. E-mail address: madrumbl@ualr.edu. This Article was presented at the International Law Association International Law Weekend (November 4-6, 1999), for a panel entitled "Evolving Law: International Human Rights in Flux." Parts (III) and (IV) of this Article expand upon concerns raised in my essay Waging War Against the World: The Need to Move from War Crimes to Environmental Crimes, 22 FordHAM INT'L L.J. 122 (1998). 
most part, the recent international evolution of human rights law has tended towards growth and expansion.

Growth can involve the creation of new mechanisms to enforce basic civil rights by holding accountable those who violate these rights. In recent years, the creation of mechanisms to promote accountability has become a focal point of activity for international lawyers. This activity has most immediately culminated in the adoption of the Rome Statute of the International Criminal Court (Rome Statute) ${ }^{1}$ in July, 1998. The Rome Statute innovates on both the procedural and substantive fronts. Along with creating an enforcement mechanism in the form of the International Criminal Court (ICC), the Rome Statute also refines prior customary and conventional rules by providing a detailed list of what can prospectively be sanctioned as the "most serious crimes of concern to the international community as a whole."2 In this regard, the Rome Statute creates important linkages between human rights, international humanitarian law, and international criminal law. This gives rise to what one scholar has labeled the "humanization" of international humanitarian law. ${ }^{3}$

Although there has been considerable parallelism between international human rights and international humanitarian law, this has, for the most part, occurred within the nexus of classic human rights such as the right to life, the right to freedom from persecution, and the right to bodily integrity. The evolution and growth of social and political rights, and their penetration into the world of international humanitarian law, has been much slower. A traditionally socio-political right whose exploration shall constitute the focus of this Article is the right to live in a healthy and productive environment, which some have called "environmental security." 4 For the most part, the linkage between international humanitarian law and environmental security is weak and may in fact reflect a somewhat troubling disjunction between international environmental law and humanitarian concerns. Although international humanitarian law may well be "humanized," it is not showing signs of being "environmentalized."

The gap between international humanitarian law and environmental security should trouble international lawyers. Just as armed conflict often creates a context in which the most serious human rights abuses occur, so too,

1. Rome Statute of the International Criminal Court, U.N. Doc. A/CONF. $183 / 9$ (1998) [Rome Statute].

2. Id. at art. $5(1)$.

3. See comments of Professor Theodor Meron at the Opening Session of the International Law Association International Law Weekend (November 4-6, 1999) (notes on file with the author).

4. See, e.g., Bernard A. Weintraub, Environmental Security, Environmental Management, and Environmental Justice, 12 PACE ENVTL. L. REV. 533, 546 (1995) ("environmental security . . refers to a community's state of assurance that its stability as a community will not be threatened by a lack of proper management of the natural resources it deems to be necessary parts of its identity"). 
does it create a similar context for the infliction of wanton and extensive destruction to the environment. This destruction creates profound environmental insecurity. Part (II) of this Article explores the insecurities caused by the environmental consequences of armed conflict. Although the international community has shown considerable concern for the humanitarian consequences of war, ${ }^{5}$ it has been significantly more hesitant in accounting for war's environmental consequences. It is for this reason that a very fruitful exploration of the progress that has been made and that still needs to be made in terms of harmonizing international humanitarian law with environmental protection can emerge from a study of how the international community monitors the environmental consequences of war. Part (III) examines the successes and failures of the international legal order in controlling these consequences and directs its focus on the ICC's jurisdiction to prosecute environmental war crimes. Part (IV) argues that the ICC may not be particularly well-suited to sanction environmentally destructive behavior. This raises the more penetrating question whether punitive criminal approaches pursued in isolation of other policy devices can ever promote environmental security. Part (V) is proscriptive, sketching ways in which the promotion of environmental security can be made more effective. Part (V) posits that the effective promotion of environmental security requires a multifaceted approach, which combines criminal prosecution, preventative measures, and specially tailored remedies. An additional element of this multifaceted approach, inspired by environmental justice litigation in the United States, involves more proactive use of international anti-discrimination conventions to guard against the infliction of environmental insecurity on already disempowered groups. In the end, this encourages environmental security to become more closely integrated with both the protection of human rights and international humanitarian law.

\section{OVERVIEW OF THE ENVIRONMENTAL CONSEQUENCES OF ARMED CONFLICT}

Modification or desecration of the natural environment has often been used as a strategic mechanism to safeguard state sovereignty. Over two mil-

5. See, e.g., 1949 Geneva Convention for the Amelioration of the Condition of the Wounded and Sick in Armed Forces in the Field, August 12, 1949, 75 U.N.T.S. 31; 1949 Geneva Convention II for the Amelioration of the Condition of Wounded, Sick and Shipwrecked Members of the Armed Forces at Sea, August 12, 1949, 75 U.N.T.S. 85; 1949 Geneva Convention II Relative to the Treatment of Prisoners of War, August 12, 1949, 75 U.N.T.S. 135; 1949 Geneva Convention IV Relative to the Protection of Civilian Persons in Time of War, August 12, 1949, 75 U.N.T.S. 287. The Security Council's creation of ad hoc International Criminal Tribunals in the former Yugoslavia and Rwanda also evinces the international community's concern for the humanitarian consequences of war. See also Rome Statute, supra note 1. 
lennia ago, Roman soldiers salted the soil of Carthage. Much more recently, Agent Orange was used to defoliate the Vietnamese jungle. In fact, it is estimated that, from 1962 to 1971 , the United States sprayed twelve million gallons of defoliant over more than ten percent of what was then South Vietnam. ${ }^{6}$ United States estimates reveal that fourteen percent of the area's forests were destroyed. ${ }^{7}$ Other estimates place the figure at nearly one-third. ${ }^{8}$ Regardless of the exact numbers, "broad stretches of the landscape are still bare of trees." Civilians and soldiers who had been exposed to defoliants claim to have passed the ill-effects through their family lines. In fact, there are tens of thousands of physically or mentally disabled children in Vietnam whose disabilities can be linked to the spraying of Agent Orange which occurred before they were born or even conceived. ${ }^{10}$

During the 1990-1991 Gulf War, vast quantities of oil were dumped into the Persian Gulf to contaminate Kuwait's water supply. ${ }^{11}$ Kuwaiti oil wells were also deliberately ignited by Iraqi troops. ${ }^{12}$ Remedying the losses and damages suffered as a direct result of Iraq's unlawful invasion and occupation of Kuwait has prompted the creation of the United Nations Compensation Commission (UNCC) as a subsidiary organ of the United Nations. ${ }^{13}$ The UNCC is a unique initiative (part court of law, part arbitral tribunal) which adopts mass tort litigation approaches to settle claims and pay compensation, including for damage to the Kuwaiti environment and public health. Iraq, whose liability is presumed, is to pay reparations out of its frozen international

6. Seth Mydans, Vietnam Sees War's Legacy in Its Young, N.Y. Times (May 16, 1999), at 12. Two commentators have argued that the Vietnam War's "environmental damages offered a rallying point for opponents of the conflict and catalyzed political animus against the war." See Peter J. Richards and Michael N. Schmitt, Mars Meets Mother Nature: Protecting the Environment During Armed Conflict, 28 STETSON L. REV. 1047, 1053 (1999).

7. Id.

8. See Oscar Arias, Responsibility of Nations to the Environment, in PROCEEDINGS OF THE FIRST INTERNATIONAL CONFERENCE ON ADDRESSING ENVIRONMENTAL CONSEQUENCES OF WAR: LEGAL, ECONOMIC AND SCIENTIFIC PERSPECTIVES (June 10-12, 1998).

9. Mydans, supra note 7.

10. There is evidence that dioxin, the poisonous residue of Agent Orange, contributes to the types of birth defects found in Vietnam. However, much of this evidence is "anecdotal" and is disputed by the United States, which persists in refusing to take responsibility. Id.

11. Richards and Schmitt, supra note 7, at 1055.

12. See Public Authority for Assessment of Compensation of Damages Resulting from Iraqi Aggression, OllandENVIRONMENTAL Claims BuLLETIN (Aug. 1997). Independent of the damage to Kuwait and to the Persian Gulf waters, it is estimated that the oil well fires set by Iraqi soldiers expelled one to two million tons of carbon dioxide, which in 1991 represented one percent of total global carbon dioxide emissions. Id. at 8. One commentator has estimated that over $\mathbf{7 0 0}$ oil wells were ignited. See Weintraub, supra note 4, at 536 .

13. Created by virtue of Security Council Resolution 687, U.N. SCOR, 2981 st mtg. at 7, U.N. Doc. S/RES/687 (1991). 
assets as well as from a portion of its future oil export earnings. Thus far, 2.6 million claims have been filed. ${ }^{14}$ The asserted value of claims is still to be resolved $\$ 320$ billion. ${ }^{15}$ Of those claims which have been resolved, nearly 15 million has been awarded in compensation to aggrieved partners.

Reports of significant ecological destruction are also emerging from the Federal Republic of Yugoslavia (FRY). NATO aerial bombardment of the FRY under Operation Allied Force has resulted in the destruction of oil refining installations as well as storage facilities for other industrial products. Much of this destruction arose from the indiscriminate effects of bombing from very high altitude levels. ${ }^{16}$ In particular, the destruction of a petrochemical, fertilizer and refinery complex in Pancevo resulted in the discharge of oil, gasoline, and dichloride (a powerful carcinogen) into the Danube river. ${ }^{17}$ The bombardment of the Pancevo facility also caused the emission of toxic gases. ${ }^{18}$ The result, according to one Western observer, is an "ecological disaster," with the pollution "spread[ing] downstream to Romania and Bulgaria and then into the Black Sea." Scientists are also very concerned that extensive flooding may result from ice which may form on the Danube and then become lodged behind three bridges in Novi Sad which were bombed during Operation Allied Force. ${ }^{20}$ The areas most at risk include low-lying portions of Serbia, as well as Croatia and parts of Hungary. ${ }^{21}$

In short, "[f]rom antiquity to the present, examples of environmental destruction in war abound."22 But it is not only actual war which creates environmental insecurity. The environment also faces severe threats as nations prepare to go to war (mobilization) and as nations turn back from the threat of

14. Jay Austin and Carl Bruch, The Greening of Warfare, 15:6 ENVIRONMENTAL ForUM 32, 33 (1998). See also, United Nations Compensation, www.UNOQ.ch/uncc/stats.htm(visited on'March 6, 2000).

15. Id.

16. One scholar has in fact argued that the patterns of the NATO bombings trigger important international humanitarian law concerns. See comments of Professor Julie Mertus, "The Imprint of Kosovo on International Law" Panel, International Law Weekend (November 4-6, 1999) (notes on file with the author).

17. Tom Walker, Missile Strikes Pollute Danube, GLOBE AND MAIL (April 19, 1999) at 1.

18. Id.

19. Id.

20. Marlise Simons, Hungary Says Danube's Bombed-Out Bridges May Cause Floods, N.Y. TIMES (October 24, 1999). One hurdle which will have to be overcome in the repair of the bridges is that the FRY government maintains there are still unexploded missiles and other ordnance in the Danube. $I d$.

21. Id.

22. Richards and Schmitt, supra note 7, at 1051. See also Neil A. F. Popovic, Huinanitarian Law, Protection of the Environment, and Human Rights, 8 GEO. INT'L ENVTL. L. REv. 67, 69 (1995) (providing examples of deliberate dam-busting by armed forces during the Second Sino-Japanese War of 1937-1945, World War II, and the Korean War). 
war (decommissioning and disarmament). ${ }^{23}$ On this latter point, Russian attempts to decommission its nuclear submarines in the Arctic Ocean are being carried out with insufficient financial and human resources and seriously threaten that particularly fragile marine environment. ${ }^{24}$ Testing of weapons specifically nuclear, biological and chemical weapons - also has particularly noxious effects on the environment. These activities collateral to actual armed conflict therefore require regulation. Nonetheless, for the most part, multilateral legal structures only provide limited supervision and monitoring for the environmental consequences of such activities.

\section{The ICC AND EnVIRonmental PROTECTION: THE LANGUAGE OF THE ROME STATUTE}

It is only very recently that the international community has made inroads into contemplating the prosecution of those who engage in unacceptable use of the environment during wartime. In this regard, the language of the Rome Statute is important. For the first time, environmental war crimes are independently sanctioned and an apparatus is provided for the punishment of those who commit such crimes. Although there was some scattered mention of environmental war crimes at the Nuremberg Trials, ${ }^{25}$ over the past five decades humanitarian abuses have been treated separately from environmental desecration. This disconnect is revealed in the Statute of the International

23. Mobilization should also include the day-to-day maintenance of military bases. It is reported that it would take "enormous diversions of money and effort to remediate the numerous hazardous waste sites that the United States military has created at its many military bases." See Weintraub, supra note 4, at 582. Should military bases not be run in an environmentally sensitive manner, the threat of environmental degradation and contamination increases.

24. Symposium Rationale, arms and the Environment: Preventing the Perils of DISARMAMENT, University of Tulsa (Dec. 9B10, 1999) ("Many of the past and potentially adverse future global environmental impacts on the Arctic caused by Russian nuclear dumping have obstructed and delayed the implementation and multiplied the costs of implementing START 1 [n.b. the Strategic Arms Reduction Treaties]. The United States, Norway, and the international community are trying, ex post, to address and prevent these unforeseen problems, but might have done so more effectively and efficiently ex ante."). See also, Elizabeth Kirk, The Environmental Implications of Arms Control Agreement (Paper on file with author).

25. See, e.g., German General Rendulic was acquitted of charges that he perpetrated a scorched earth policy as his forces evacuated Norway. See The Hostage Case (U.S. v. List), 11 T.W.C. 759 (1950). Rendulic alleged he believed his forces were being chased by Soviet forces. As a result, he maintained that the environmental destruction was militarily necessary. As it tumed out, Rendulic's forces were not being chased by Soviet forces. However, it was held that Rendulic's belief, although mistaken, was reasonably held. Id. The Rendulic case is a classic example of the operation of military necessity as a defense to environmental crimes. See Ensign Florencio J. Yuzon, Deliberate Environmental Modification through the Use of Chemical and Biological Weapons: 'Greening' the International Laws of Armed Conflict to Establish an Environmentally Protective Regime, 11 AM. U. J. INT'L L. \& POL'Y 793, 815 (1996). 
Criminal Tribunal for the Former Yugoslavia ${ }^{26}$ and the Statute of the International Criminal Tribunal for Rwanda. ${ }^{27}$ Neither Tribunal is directly empowered to prosecute those who propagate environmental insecurity through the commission of environmental war crimes. The International Criminal Tribunal for the Former Yugoslavia has some jurisdiction over war crimes which bear an incidental relationship to the security of the natural environment. ${ }^{28}$ The International Criminal Tribunal for Rwanda essentially lacks jurisdiction over even incidental violations of environmental security. ${ }^{29}$

26. U.N. SCOR 827, U.N. Doc. S/RES/827 (May 25, 1993), Annex [hereinafter Statute of the ICTY].

27. U.N. SCOR 955 S.C. Res. 955, U.N. SCOR, 3453d mtg., (Nov. 8, 1994), Annex [hereinafter Statute of the ICTR].

28. The ICTY has jurisdiction over a series of war crimes. See Statute of the ICTY, supra note 27, art. at 3. Environmental desecration does not figure among the listed crimes. There is, however, jurisdiction over a series of war crimes which bear an incidental relationship with environmental insecurity. See id. These include: employment of poisonous weapons (art. 3(a)); wanton destruction of cities, towns or villages, or devastation not justified by military necessity (art. 3(b)); attack, or bombardment, by whatever means, of undefended towns, villages, dwellings, or buildings (art. 3(c)); and plunder of public property (art. 3(e)). The ICTY can also prosecute as a war crime the extensive destruction and appropriation of property, not justified by military necessity and carried out unlawfully and wantonly (art. 2(d)). However, these crimes do not involve environmental destruction as a crime per se. Instead they focus on damage to human environments and property. Without the immediate causal link to human harm there can be no liability. This provides no jurisdiction to hold individuals accountable for wanton environmental destruction, regardless of the long-term effects of that destruction on human life or environmental security. The ICTY's jurisdiction over war crimes is not limited to those enumerated in the Statute of the ICTY. Id. at art. 3. However, so far no one has been prosecuted for environmental war crimes. See Preparatory Commission Request, infra note 39, at 29. As a result, the ICTY has not been called upon to decide whether it has the discretionary jurisdiction to address such crimes. Id.

29. Statute of the ICTR, supra note 28 , at art. 4 . One crime over which the ICTR has jurisdiction that bears a remote relationship to the environment is "pillage." $l d$. at art. 4(f). Jurisdiction can also be exercised over "violence to health of persons" and "acts of terrorism." Id. at arts. 4(a) and 4(d). Both of these crimes have an even more remote relationship with the protection of the natural environment. However, there have been no charges involving these war crimes. Given the profound environmental insecurity arising out of the Rwandan conflict, the lack of jurisdiction over environmental war crimes is disappointing. The Rwandan conflict has seen two national parks (Parc national des volcans and Parc national de l'Akagéra) landmined, endangered species (the mountain gorillas) poached, agricultural lands rendered barren in order to coerce the migration of persecuted peoples, and systemic resettlement exhausting moderate lands specifically in eastern Congo of their agricultural capacities. See Mark Drumbl, Rule of Law Amid Lawlessness: Counseling the Accused in Rwanda's Domestic Genocide Trials, 29 COLUM. HUM. RTS. L. REV. 545 (1998). The domestic war crimes prosecutions which are occurring in Rwanda have also been completely reticent in the area of environmental crimes. 
Under the language of the Rome Statute, however, intentional infliction of harm to the environment may constitute a war crime. ${ }^{30}$ More specifically, Article $8(2)(b)(i v)$ prohibits [emphasis added]:

Intentionally launching an attack in the knowledge that such attack will cause incidental loss of life or injury to civilians or damage to civilian objects or widespread, long-term and severe damage to the natural environment which would be clearly excessive in relation to the concrete and direct overall military advantage anticipated. ${ }^{31}$

The negotiation history of Article 8(2)(b)(iv) merits a brief review. The draft of the Rome Statute which served as the basis for the final negotiations listed three other options along with the language which was eventually adopted in Article 8(2)(b)(iv). ${ }^{32}$ The three rejected options are:

1. Intentionally launching an attack in the knowledge that such attack will cause incidental loss of life or injury to civilians or damage to civilian objects or widespread, long-term and severe damage to the natural environment which is not justified by military necessity; (Or)

2. Intentionally launching an attack in the knowledge that such attack will cause incidental loss of life or injury to civilians or damage to civilian objects or widespread, long-term, and severe damage to the natural environment;

(Or)

3. No paragraph [in other words, no prohibition on intentionally inflicting widespread, long-term and severe damage to the natural environment].

In the end, the provision which was adopted was a compromise and, from an environmental perspective, occupies a middle ground. However, it shares with the first option the important limitation that environmental integrity is secondary to the military advancement of national security interests. There are other important limitations. The jurisdiction of the ICC is restricted to "war

30. Rome Statute, supra note 1, at art. $5(1)(\mathrm{c})$ (vesting the ICC with jurisdiction over war crimes). Articles 5(1)(d) and 5(2) create jurisdiction over "crimes of aggression." However, the definition of this term is not provided; in fact, the Rome Statute leaves it to the parties to define this term in the future. Id. Those concerned with environmental issues may view the open-ended nature of crimes of aggression as a potential device to expand the ICC's jurisdiction over environmental matters.

31. Id. at art. 8(2)(b)(iv)(emphasis added).

32. Preparatory Committee on the Establishment of an International Criminal Court, U.N. Doc. A/AC.249/1998/CRP.8 (2 April 1998), section B(b) to the "War Crimes" section of Part 2 (visited Feb. 18, 2000) <http://www.un.org/icc> [hereinafter "Draft Rome Statute"]. The Draft Rome Statute is on file with the author. 
crimes in particular when committed as a part of a plan or policy or as part of a large-scale commission of such crimes." ${ }^{33}$ The question consequently arises whether the "in particular" language will allow isolated incidents to fall within the purview of the Rome Statute. A more important limitation, however, is the fact that prohibiting harm to the natural environment is explicitly mentioned only once in the entire Rome Statute. ${ }^{34}$ This provision may therefore become peripheral given the broad array of other crimes to which the ICC's energies will be directed. As a result, the effect of this provision may well be more apparent than real. Also, the environmental war crimes provision of the Rome Statute only applies to inter-state armed conflicts. Environmental desecration during internecine conflicts is consequently left unaddressed. ${ }^{35}$ This is a

33. Rome Statute, supra note 1, at art. 8(1). Another limitation to the effectiveness of the ICC in the area of war crimes is the fact that any signatory state can opt out of the ICC's jurisdiction over war crimes alleged to have been committed by that state's nationals or on that state's territory. See id. at art. 124 .

34. In other places, the Rome Statute prohibits as a "war crime" conduct which may be collaterally related to the well-being of the natural environment, or have some other ancillary connection. See, e.g., id. at art. 8(2)(a)(iv) (sanctions extensive destruction and appropriation of property not justified by military necessity and carried out unlawfully and wantonly). Article $8(2)$ (b) prohibits other serious violations of the laws and customs applicable in international armed conflict, within the established framework of international law, namely: (ii) Intentionally directing attacks against civilian objects; (iii) Intentionally directing attacks against . . installations, material . . . involved in a humanitarian assistance or a peacekeeping mission; ( $v$ ) Attacking or bombing... dwellings or buildings which are undefended and which are not military objectives; (ix) Intentionally directing attacks against ... [inter alia] historic monuments; (xiii) Destroying or seizing the enemy's property unless such destruction or seizure be imperatively demanded by the necessities of war; (xvi) Pillaging a town or place; (xxv) Intentionally using starvation of civilians as a method of warfare by depriving them of objects indispensable to their survival. The Rome Statute also criminalizes the use of certain weapons with destructive effects on both humanity as well as the natural environment. See id. at art. 8(2)(b). Prohibited practices include: (xvii) Employing poison or poisoned weapons; (xviii) Employing asphyxiating, poisonous or other gases, and all analogous liquids, materials or devices. Many of these weapons are already prohibited by other international agreements. See, e.g., Convention on Prohibitions or Restrictions on the Use of Certain Conventional Weapons Which May be Deemed to be Excessively Injurious or to Have Indiscriminate Effects, 35 U.N. GAOR, 35th Sess., U.N. Doc. AVCONF 95/15, Oct. 27, 1980, 19 I.L.M. 1523; Protocol for the Prohibition of the Use in War of Asphyxiating, Poisonous or Other Gases, and of Bacteriological Methods of Warfare, June 17, 1925, 26 U.S.T. 571; Convention on the Prohibition of the Development, Production and Stockpiling of Bacteriological (Biological) and Toxin Weapons and on their Destruction, Apr. 10, 1972, 26 U.S.T. 583; Convention on the Prohibition of the Development, Production, Stockpiling and Use of Chemical Weapons and on Their Destruction, Jan. 13, 1993, 32 I.L.M. 800.

35. See Rome Statute, supra note 1, at arts. $8(2)(c) \&(e)$. These articles list the types of war crimes punishable within internal armed conflicts. Intentionally inflicting widespread, long-term and severe harm to the environment is omitted from this list. Basic principles of treaty interpretation provide that this omission is deliberate and evinces a desire not to punish environmental desecration when committed in an internal conflict. Further limitations on the application of the entire Rome Statute to internal conflicts are found in Article $8(2)(f)$, which provides.

Paragraph 2(e) applies to armed conflicts not of an international character and thus does not apply to situations of internal disturbances and tensions, such as riots, isolated and sporadic acts of violence or other acts of a similar nature. It applies to armed conflicts that take place in the territory of a State when there is 
troubling gap. ${ }^{36}$ Also troubling is the fact that the ICC can only capture environmental crimes committed by military forces actively engaged in hostilities. There is therefore no jurisdiction to sanction the environmental insecurity created by armed forces in the testing of weapons or in the mobilization of forces. Nor is there jurisdiction to supervise any disarmament process, ${ }^{37}$ notably the modalities of decommissioning and their environmental effects.

Article 8(2)(b)(iv) also triggers more specific interpretive concerns. By way of overview, there are three principal components to the language of Article 8(2)(b)(iv): (1) the actual physical act - or actus reus - which consists of launching an attack which causes "widespread, long-term and severe damage" to the natural environment; (2) a second material element, namely that the damage must be "clearly excessive" in relation to the "concrete and direct overall military advantage anticipated"; and (3) even if both material elements are found, the mental element - or mens rea - must be demonstrated, thereby entailing proof that the attack was launched intentionally and in the knowledge it will cause "widespread, long-term, and severe damage" to the natural environment.

protracted armed conflict between governmental authorities and organized armed groups or between such groups. Id. [emphasis added]. In sum, nations appear less willing to criminalize conduct in internal conflicts than in international conflicts. This gives rise to concern that the protection of both humanity and the environment in internal conflicts may be inadequate. However, even the limited jurisdiction obtained over internal conflicts represents a major step forward. After all, such intrusion into internal affairs is one of the most jealously guarded elements of state sovereignty.

36. See discussion of the environmental effects of internal conflicts in Rwanda, supra note $\mathbf{3 0 .}$ There are other examples of intentional environmental degradation occurring during internal conflicts. See infra note 134, for a discussion of the effects of the El Salvadoran, Nicaraguan, and Colombian conflict. In the Colombian conflict, it is reported that a "guerrilla group ... attempted to undermine the authority of the government by repeatedly blowing up the nation's largest oil pipeline, spilling more than 600,000 gallons of oil into east Andes wetlands." See Weintraub, supra note 4, at 583, citing James Brooke, Colombia Rebels Turn to Ecological Terrorism, N.Y. TIMES (Oct. 29, 1990). Insurgency and counter-insurgency guerilla civil wars have a particularly devastating effect on local environments. Insurgents often use tropical forests as home bases and hiding grounds; counter-insurgency forces often respond by slashing and burning forests, together with polluting rivers. The Cambodian conflict reflects a different, yet equally destructive, misuse of the environment during an internal armed conflict. It is reported that "the Khmer Rouge has survived in the rainforests on the Thai-Cambodian border by decimating the forests there and selling concessions to log the timber and mine whatever minerals can be found in that region. This abuse of Cambodia's natural resources can be understood to be a threat not only to Cambodia's environmental security . . . but also to the environmental security of all those who rely on, or support, the protection of the Cambodian rainforests." See id. at 602-03.

37. Supra note 25 ("disarming nuclear and chemical weapons and weapon systems does ... create environmental impacts"). 


\section{A. The Physical Act: Widespread, Long-term and Severe Damage}

A successful prosecution under the Rome Statute will, first and foremost, have to show that the accused launched an attack ${ }^{38}$ which caused "widespread, long-term, and severe damage to the natural environment." Of great importance is that all three elements must conjunctively be proven. The language of "widespread, long-term and severe" has woven its way into the handful of other international humanitarian conventions which address the use of the environment in times of war, for example the 1977 United Nations Convention on the Prohibition of Military or Any Other Hostile Use of Environmental Modification Techniques (ENMOD Convention), ${ }^{39}$ and the 1977 Additional Protocol I to the 1949 Geneva Convention (Protocol I). ${ }^{40}$ However, by providing that all three elements must be conjunctively shown to exist, the

38. "Attack" has been defined as an act of violence against the adversary, whether in offence or defense." See Protocol I on the Protection of Victims of International Armed Conflicts, opened for signature Dec. 12, 1977, 1125 U.N.T.S. 3 (entered into force Dec. 7, 1978) [hereinafter Protocol I], art. 49(1). See also

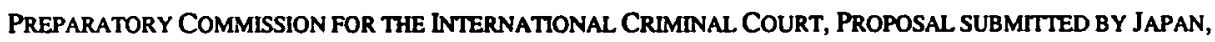
U.N. Doc. PCNICC/1999/WGECJDP.12 (July 22, 1999). The attack cannot be isolated or sporadic, but must involve the Ause of armed force to carry out a military operation during the course of an armed conflict." See REQUEST FROM THE GOVERNMENTS OF BELGIUM, COSTA RICA, FINLAND, HUNGARY, THE REPUBLIC OF KOREA, SOUTH AFRICA AND THE PERMANENTOBSERVER MISSION OF SWTTZERLAND TO THE UNITED NATIONS REGARDING THE TEXT PREPARED BY THE INTERNATIONAL COMMITTEE OF THE RED CROSS ON ARTICLE 8, $\mathbb{T}$ 2(B), (I), (II), (III), (IV), (V), (VI), (VII), (IX), (XI) AND (XII) OF THE STATUTE, UN Doc. PCNICC/1999/WGEC/ INF.2/Add.1 (July 30, 1999) 29 [hereinafter Preparatory Commission Request].

39. United Nations Convention on the Prohibition of Military or Any Other Hostile Use of Environmental Modification Techniques, May 18, 1977, 31 U.S.T. 333 (entered into force Oct. 5, 1978) [ENMOD Convention], which prohibits engagement "in military ... environmental modification techniques having widespread, long-lasting or severe effects as the means of destruction, damage, or injury to any other State Party." The ENMOD Convention focuses on the use of the environment as a weapon - as a result, wanton destruction of the environment occurring as a byproduct of a military campaign might not fall within its parameters. See Richards and Schmitt, supra note 7, at 1063 ("[T] 1977 ENMOD Convention . . merely limits the use of modification of the environment as a tool or weapon of warfare."). Environmental damage per se is for the most part not a concern of the ENMOD Convention. See Richards and Schmitt, supra note 7, at 1063. Some of the activities prohibited by the ENMOD Convention amount to outrageous behavior not within the military capability of most nations for example: inducing earthquakes and tidal waves, or activating quiescent volcanoes.

40. Protocol I, supra note 39, at art. 35(3) (prohibits "methods or means of warfare which are intended, or may be expected, to cause widespread, long-term and severe damage to the natural environment"). Id. at art. 55 states that:

Care shall be taken in warfare to protect the natural environment against widespread, long-term and severe damage. This protection includes a prohibition on the use of methods or means of warfare which are intended or may be expected to cause such damage to the natural environment and thereby to prejudice the health or survival of the population. Attacks against the natural environment by way of reprisals are prohibited. See also id. at arts. 54, 56 (which provide for the protection of property, which bas ancillary benefits for the environment.) The United States has not yet ratified Protocol I, in part owing to objections over its environmental provisions. See Richards and Schmitt, supra note 7, at 1054. 
language of the Rome Statute regresses from the wording of the ENMOD Convention which bases fault disjunctively on proof of only one of these three characteristics.

What exactly do "widespread," "long-term," and "severe" mean? The Rome Statute is silent on this point. The International Law Commission (ILC) has concluded that "widespread, long-term and severe" describes the "extent or intensity of the damage, its persistence in time, and the size of the geographical area affected by the damage." ${ }^{41}$ However, the International Committee of the Red Cross (ICRC) recognizes that the more specific question "as to what constitutes 'widespread, long-term, and severe' damage ... to the environment is open to interpretation." ${ }^{, 42}$ In this regard, some interpretive guidance can be provided by the work of the Geneva Conference of the Committee on Disarmament Understanding (CCD Understanding) regarding the application of these terms under the ENMOD Convention. ${ }^{43}$ This additional work was necessary since the ENMOD Convention does not itself define these terms. The CCD Understanding provides as follows:

1. "Widespread" encompassing an area on the scale of several hundred square kilometers;

2. "Long-term" lasting for a period of months, or approximately a season;

3. "Severe" involving serious or significant disruption or harm to human life, natural and economic resources or other assets.

Regrettably, the interpretive value of the CCD Understanding is curtailed by the fact that it stipulates that its use is limited to the ENMOD Convention and is not intended to prejudice the interpretation of similar terms if used in another international agreement. ${ }^{44}$ As the ENMOD Convention deals with "extraordinary manipulations of the natural environment for military purposes, such as creating floods, it is unclear what weight, if any, it would be given by the [ICC]." ${ }^{45}$ As it turns out, greater interpretive guidance may be obtained from commentaries on Protocol I, especially since its language is, like the Rome

41. UN Doc. A/CN.4/SR.2241, 22 August 1991, pp. 15, 18, cited in Preparatory Commission Request, supra note 39, at 33.

42. UN Doc. A/48/269, p. 9. See also Doc. A/47/328, 31 July 1992, paras. 20, 63, cited in Preparatory Commission Request, supra note 39, at 34.

43. Understanding I of the Conference of the Committee of Disarmament, reprinted in Convention on the Prohibition of Military or Any Other Hostile Use of Environmental Modification Techniques: Hearing Before Senate Comm. On Foreign Relations, 95th Cong. 2d Sess. (1978) [CCD Understanding].

44. Id. (It is further understood that the interpretation set forth above is intended exclusively for this Convention and is not intended to prejudice the interpretation of the same or similar terms of used in connection with any other international agreement.). See also Richards and Schmitt, supra note 7, at 1065.

45. Austin and Bruch, supra note 15 , at 38 . 
Statute's, conjunctive in nature. From an environmental perspective, the prohibitions in Protocol I are more circumscribed than those of ENMOD. For example, "long-term" has been interpreted by the ICRC as meaning lasting for "decades rather than months." 46

The "widespread" and "long-term" principles attempt to ascribe temporal and geographic limitations to environmental harm which, for the most part, does not know such boundaries. As the planet constitutes one single ecosystem, environmental degradation of one part of the earth ultimately affects the entire planet. ${ }^{47}$ The "severe" requirement could mean that damage to an isolated section of the global commons whose natural resources have not yet been valued by global financial markets could escape punishment; and this notwithstanding its biodiversity or species-importance. The anthropocentric limitation of "severe" damage to that which affects human life and human consumption of natural resources underscores a more general shortcoming with much of the existing framework of environmental protection during wartime namely that this protection is not geared to protecting the environment per se, but, rather, humanity's need to make use of it. More troubling is that state practice in some of the signatories to the Rome Statute ascribes the anthropocentric limitation to the totality of the material element of Article 8(2)(b)(iv). For example, the German Military Manual states that: “'Widespread,' 'long-term,' and 'severe' damage to the natural environment is a major interference with human life or natural resources." 48

An additional phrase that requires definition is "natural environment." In its report detailing the work of its 43rd Session, the ILC offered a broad definition of "natural environment." 49 This definition focused both on the

46. UN Doc. A 48/269, p. 9. See also Jozef Goldblat, The Mitigation of Environmental Disruption by War: Legal Approaches, in ENVIRONMENTAL HAZARDS OF WAR: RELEASING DANGEROUS FORCES IN AN INDUSTRIALZED WORLD 52 (Arthur Westing ed. 1990). The ILC has concluded that Along-term" should be taken to "mean the long-lasting nature of the effects and not the possibility that the damage would occur a long time afterwards." See UN Doc. A/CN.4/SR.2241, 22 August 1991, pp. 15, 18, cited in Preparatory Commission Request, supra note 39, at 33.

47. Lynn Berat, Defending the Right to a Healthy Environment: Toward a Crime of Geocide in International Law, 11 B.U. INT'L L.J. 327, 347 n.102 (1993).

48. Humanttarian Law In ARMed CONflicts Manual (Germany), No. 403, 37 (1992), cited in Preparatory Commission Request, supra note 39, at 34. More broadly, the fact that the environmental war crimes is clustered by the Working Group on the Elements of Crimes with provisions entirely focused on damage to the human environment gives further credence to the concern that the delegates to the Preparatory Commission may not see Article 8(2)(b)(iv) operating beyond these anthropocentric limitations. See Preparatory Commission for the International Criminal Court, Second Session, 26 July to 13 August 1999, $<$ http://www.un.org/law/icc/prepcpmm/prepjul.htm> (visited October 18, 1999) [Preparatory Commission for the International Criminal Court, Second Session].

49. GAOR, 46th session, suppl. No. 10 (U.N. Doc. A/46/10), p. 276, cited in Preparatory. Commission Request, supra note 39, at 33. 
human environment as well as on the natural environment per se. ${ }^{50}$ Having such a broad definition is necessary for Article $8(2)(b)(i v)$ to fully encompass environmental security as opposed to only covering the protection of human environments (e.g. cities, dwellings, private property) from destruction. The ILC definition of the "natural environment" is as follows:

The words "natural environment" should be taken broadly to cover the environment of the human race and where the human race develops, as well as areas the preservation of which is of fundamental importance in protecting the environment. These words therefore cover the seas, the atmosphere, climate, forests and other plant cover, fauna, flora and other biological elements. ${ }^{51}$

It will be important to develop a memorandum of understanding under the Rome Statute in which the scope of "natural environment," "widespread," "long-term," and "severe" is spelled out. The ongoing Preparatory Commission sessions provide an appropriate forum for such discussions. In fact, the Preparatory Commission intends to "ensure the formulation of generally acceptable elements of crimes on Article 8, as part of a complete set of elements of crimes for all crimes, laid down in the [Rome] Statute." 52 Unfortunately, thus far specific discussion of the environmental war crime provision has been very limited. ${ }^{53}$ Nonetheless, it is essential to the viability of

50. Id.

51. Id.

52. See Preparatory Commission for the International Criminal Court, Second Session, supra note

49.

53. The Working Group on the Elements of Crimes regularly meets during the Preparatory Commission sessions. See id. So far, it has considered the elements of some of the war crimes enumerated in the Rome Statute. It has divided the war crimes provisions into nine clusters based on "the possible commonality of their elements." Id. Art. $8(2)(b)(i v)$ is clustered with arts. $8(2)(b)(v)$ [attacking or bombarding, by whatever means, towns, villages, dwellings or buildings which are undefended and which are not military objectives], (ix) [intentionally directing attacks against buildings dedicated to religion, education, art, science or charitable purposes, historic monuments, hospitals and places where the sick and wounded are collected, provided they are not military objectives], and (xxiv) [intentionally directing attacks against buildings, material, medical units and transport, and personnel using the distinctive emblems of the Geneva Conventions in conformity with international law]. Id. So far, several discussion papers have been proposed by the Working Group on the Elements of Crimes. No discussion paper has been prepared for Article 8(2)(b)(iv). Id. The official website for the Preparatory Commission addresses this gap in the following manner: "there was not sufficient time for the Coordinator to prepare discussion papers on the elements of all the provisions of war crimes." Id. Of the 23 national government proposals submitted to the Working Group on Elements of Crimes, only a handful made mention of Article 8(2)(b)(iv). See Rome Statute of the International Criminal Court, List of documents issued at the second session of the Preparatory Commission, <http://www.un.org/law/icc/prepcomm/g/docs2nd.htm> (visited October 19, 1999). Only one of these proposals gave thorough treatment to Article 8(2)(b)(iv). See Preparatory Commission Request, supra note 39. There is no indication this trend will change in upcoming Preparatory Commission sessions. 
Article $8(2)$ (b)(iv) that the definition of the elements it contains is not pitched at such a high level so as to strip the provision of any practical effect. This may well require the threshold of responsibility to be relaxed from the international community's current understanding of the meaning of "widespread," "longterm," and "severe" harm.

\section{B. Exculpatory Effects of Military Advantage}

Even if there is proof of widespread, long-term and severe damage to the natural environment, liability is only found if this damage is "clearly excessive" in relation to the "concrete and direct overall military advantage anticipated."

This second material element permits "military objectives [to be] offered as a defense against charges of environmental damage, even intentional damage, as long as that damage is outweighed by the expected military gain." 54 The exculpating force of "proof of military advantage" traces its roots to the doctrine of "military necessity." This doctrine has historically been used to mitigate or eliminate responsibility often for grievous breaches of humanitarian standards. In short, "military necessity" is a principle of customary international law 55 "which 'authorizes' military action when such action is necessary for the overall resolution of a conflict, particularly when the continued existence of the acting state would otherwise be in jeopardy." 56 At the Nuremberg trials, the doctrine of military necessity was applied to the destruction of property (the closest the international community has yet come to an environmental war crimes proceeding) in the following manner:

The destruction of property to be lawful must be imperatively demanded by the necessities of war. Destruction as an end in itself is a violation of international law. There must be some reasonable connection between the destruction of property and the overcoming of the enemy forces. ${ }^{57}$

"Military advantage" may bear an even lower threshold of proof than "military necessity." As a result, the prohibition in Article 8(2)(b)(iv) may be narrower than its antecedents at customary international law. In the case of

The fact that little individualized attention is given to the environmental war crimes provision notwithstanding its fundamentally different nature than the other war crimes may foreshadow the possibility that the environmental war crime is simply not taken particularly seriously within the spectrum of offenses contained within the Rome Statute.

54. Austin and Bruch, supra note 15 , at 39.

55. See Preparatory Commission Request, supra note 39, at 28, nn. 32-33.

56. Mark J.T. Caggiano, The Legitimacy of Environmental Destruction in Modern Warfare: Customary Substance over Conventional Form, 20 B.C. ENVTL. AFF. L. REV. 479, 496 (1993).

57. The Hostage Case, supra note 26, 11 T.W.C. at 1254. 
Article $8(2)(b)(i v)$, the ambit of "military advantage" is limited by the fact that only "concrete and direct overall military advantage anticipated" can justify the environmental damage. Nonetheless, "concrete and direct overall military advantage anticipated" still seems easier to prove than "military necessity." In addition, although the "military necessity" defense may in fact form part of customary international law, it is noteworthy that Protocol I, in its prohibition of "widespread, long-term and severe" harm, did not permit proof of any military advantage or necessity to eliminate wrongdoing. ${ }^{58}$ As a result, Article $8(2)$ (b)(iv)'s prohibition is but a diluted version of that in Protocol I.

There are other concerns with "military advantage" in Article 8(2)(b)(iv). First, although a "proportionality test" (i.e. the environmental damage must be clearly excessive in relation to the concrete and direct overall military advantage) is established, no guidelines, definitions or examples of "clearly excessive" are provided. In fact, "the addition of the word[ ] 'clearly' ... in the definition of collateral damage is not reflected in any existing legal source." 59 To this end, memoranda of understanding of the Parties to the Rome Statute or initial decisions by the ICC will be important in setting the scope for "clearly" excessive.

Second, the factual element of the proportionality test is also unclear: since proof of "clearly excessive" is required in order to find someone guilty, and since the burden of proof rests with the Prosecutor, what type of research and data will have to be marshaled? In addition, adjectival terms such as "concrete" and "direct" and "overall" military advantage are somewhat vague and have not yet been comprehensively defined by international law. Nor does the Rome Statute provide more particularized definitions of the meaning of these terms. As for "overall," the ICRC has suggested that it indicates "that a particular target can have an important military advantage that can be felt over a lengthy period of time and affect military action in areas other than the vicinity of the target itself." ${ }^{60}$ In the end, the extent to which these adjectives qualify or extend the exculpating effect of military advantage will bear heavily on the ability of Article 8(2)(b)(iv) to punish environmental crimes.

58. See Protocol I, supra note 39, at arts. 35, 55. See also Richards and Schmitt, supra note 6, at 1062 ("No other considerations, such as the military advantage offered by the prohibited act, the possibility that alternative operations will result in greater incidental injury to civilians or collateral damage to civilian property, or the overall impact of the action in context, can trump the principle of environmental protection"). Protocol I did use the military advantage limitation for other violations (e.g., the safety of civilians). See Protocol I, supra note 39, at arts. 51, 52, 57. As a result, interpretive assistance of the meaning of "military advantage" in the Rome Statute can flow from the use of the term "military advantage" in Protocol I. Any such assistance is, of course, limited by the fact that "military advantage" in Protocol I does not figure into its treatment of the environmental war crime.

59. See Preparatory Commission Request, supra note 39, at 29.

60. See U.N. Doc. AVCONF.183/INF/10 (July 13, 1998). 
Finally, the military advantage needs simply to be "anticipated." What does this term signify? Some clarification as to the meaning of "anticipated" can emerge from a consideration of state declarations made to the use of "military advantage" in prior international conventions. It is reported that:

A number of [s]tates expressed their understanding that the military advantage anticipated from an attack is intended to refer to the advantage anticipated from the attack considered as a whole and not from isolated or particular parts of the attack. ${ }^{61}$

On a related note, it is unclear by whom and according to what standards the "anticipation" is to be judged. Does there have to be an objective element to the anticipation, or can the belief be subjectively held yet unrealistic? If the notion of military advantage remains subjective in the mind of the military or political leader under the circumstances in which the tactical decision was made, then the defense could be too widely available. In order to curtail misuse of the defense, it will be important to establish some objective standards as to when the military advantage of an attack may justify widespread, long-term, and severe damage to the environment.

The difficulties which inhere in giving appropriate meaning to the defense of military advantage raise more penetrating questions. These questions militate in favor of reconsidering the interaction between international environmental law and international humanitarian law. Certain practices - such as genocide and torture - have been sanctioned as illegal by the international community to the extent that they can never be undertaken even if essential to defend national sovereignty. Why should intentional environmental desecration not be similarly proscribed?

\section{The Mental Element: Strict Intentionality}

In the case of Article 8(2)(b)(iv), criminal sanction will only fall upon an individual who knows his or her behavior will cause widespread, long-term, and severe damage to the environment which is clearly excessive in relation to the overall military advantage anticipated and, notwithstanding proof of this knowledge, still commits the act with the full intention of causing the environmental damage. More concisely, the perpetrator must be found to have

61. Preparatory Commission Request, supra note 39, at 30. This is the position taken by the governments of Belgium, Canada, Germany, Italy, the Netherlands, Spain, and the United Kingdom in regard to Protocol I. Australia and New Zealand have declared that military advantage anticipated refers to the Abona fide expectation that the attack will make a relevant and proportional contribution to the objective of the military attack involved." Id. Commentators have also linked the military advantage of the specific attack in question to the purposes of the military operation taken as a whole. Id. at 31 . 
acted willfully and in the knowledge that the attack will cause the prohibited environmental damage. ${ }^{62}$ The Rome Statute therefore "presupposes that the attack was launched in the knowledge that [the] consequences listed occur."63 The ICRC has interpreted the phrase "in the knowledge" as requiring "the person committing the act [to know] with certainty that the described results would ensue, and this would not cover recklessness." 64 The fact that there is no liability for negligently or carelessly inflicting widespread, long-term, and severe damage to the environment means that persons who are found to act negligently will not face any sanction at all. The provision therefore covers only the most invidious offender. It goes without saying that proving this very onerous intentionality requirement will not be easy.

As a result, a more proactive approach may be required. Military and political officials in both developing and developed nations should be educated on the environmentally harmful effects of certain types of warfare, and be informed of the technologies to avoid reliance on such strategies in the first place. In this regard, the work of the ICRC can play a pivotal role. The ICRC has published a document entitled Guidelines for Military Manuals and Instructions on the Protection of the Environment in Times of Armed Conflict (Guidelines), which are:

Intended as a tool to facilitate the instruction and training of armed forces in an often neglected area of international humanitarian law: the protection of the natural environment. The Guidelines ['] . . sole aim is to contribute in a practical and effective way to raising awareness ... [T] hey are an instrument for dissemination purposes. ${ }^{65}$

The Guidelines state that they are drawn from existing international legal obligations and, as such, constitute a baseline of jus commune among nations. ${ }^{66}$

62. Id. at 27 .

63. Id. at 34.

64. Zimmermann, in COMMENTARY ON THE AdDTTONAL PROTOCOL I, art. 85, No. 3479, at 996, cited in Preparatory Commission Request, supra note 39, at 34.

65. Follow-up to the International Conference for the Protection of War Victims, Guidelines for Military Manuals and Instructions on the Protection of the Environment in Times of Armed Conflict, INTERNATIONAL REVIEW OF THE RED CROSS, No. 311, 230-237 (March 1, 1996); published as an annex to U.N. Doc. A 49/323 (1994) <http://www.icrc.org/unicc/icrenews.nsf/8> [Guidelines]. The United Nations General Assembly invited all states to widely disseminate these Guidelines and to give due consideration to the possibility of incorporating them into their military manuals. See GA Res. 49/50 (Dec. 9, 1994), art. 11. See also San Remo MaNuAL on INTERNATIONAL LAW APPLICABLE to ARMEd Conflucts at SEa (Louise Doswald-Beck, ed.) (Cambridge University Press, 1995) for a restatement of the law applicable to armed conflicts at sea. Many of the principles in the San Remo Manual are encapsulated in the general provisions of the Guidelines.

66. Guidelines, supra note 65 , at art. I(1). 
Many detailed rules are provided in Article III(9) of the Guidelines, which cover numerous issues ranging from barring incendiary weapons in forested regions to precluding the use of naval mines. Ultimately, it is hoped that the Guidelines could constitute the specific level of objective knowledge imputed to all military and civilian leaders and agents for purposes of culpability under Article 8(2)(b)(iv) of the Rome Statute. It is also hoped that they will be taken into account as new weaponry is developed. In this latter regard, Article IV(18) of the Guidelines is particularly important:

In the study, development, acquisition or adoption of a new weapon, means or method of warfare, states are under an obligation to determine whether its employment would, in some or all circumstances, be prohibited by applicable rules of international law, including those providing protection of the environment in times of armed conflict. ${ }^{67}$

In conclusion, unless some level of objective knowledge is read into the intentionality requirement, individuals who choose not to inform themselves that what they are doing is destructive of the environment might be able to use their ignorance as a full defense. A failure to incorporate an objective element into the Rome Statute's environmental war crimes also represents a step backwards insofar as Protocol I had, as early as 1977, grounded responsibility not in intentional environmental harm, but simply when there was a reasonable expectation that environmental damage would occur. ${ }^{68}$

\section{IS IT WORTH GREENING THE ICC?}

International lawyers need to consider whether the interests of the global environment are in fact well-served by collapsing environmental crimes within an overarching multilateral mechanism. If so, then an important subsidiary question emerges: is the ICC the appropriate mechanism or should a new environmentally specific entity be created? The most immediate countervailing option to proceeding multilaterally would be to address environmental crimes within the rubric of independently negotiated regional agreements. In such cases, domestic courts, regional tribunals, or either domestic or regional regulatory agencies could serve as enforcement mechanisms.

Efforts at the regional level may prove effective in combating environmental crimes within and outside the context of armed conflict. By way

67. Id. at art. IV(18).

68. Background Paper, in Proceedings of the First INTERNATIONAL. CONFERENCE ON ADDRESSING ENVIRONMENTAL CONSEQUENCES OF WAR: LEGAL, ECONOMIC AND SCIENTIFIC PERSPECTIVES (June 10-12, 1998) 5; See also Preparatory Commission Request, supra note 39, at 34. 
of example, in March, 1999, six African countries established an "African Interpol" to fight wildlife crime. ${ }^{69}$ More sweeping is the Council of Europe's Convention on the Protection of the Environment Through Criminal Law. ${ }^{70}$ The motivation behind the Convention is that signatories should take effective measures to ensure that the perpetrators of environmental hazards having serious consequences escape neither prosecution nor punishment. ${ }^{71}$ This Convention obliges signatories to criminalize certain intentional or negligent forms of environmental offenses (although the negligence may be limited by declaration to acts of gross negligence only). ${ }^{72}$ Specific examples are provided. For instance, the intentional discharge of ionizing radiation into the air, soil, or water which causes a "significant risk" of death or serious injury is to be prohibited. ${ }^{73}$ So, too, is the unlawful disposal or transport of hazardous waste which causes or is likely to cause death, serious injury, or "substantial damage to the quality of air, soil, water, animals, or plants." 74 This latter provision is important for it goes beyond the anthropocentric approach to assessing environmental harm which often characterizes current conventions and laws.

However, these successful regional initiatives should not obscure the importance of multilateral efforts. The two levels can in fact operate contemporaneously. As for the ICC, in order for it to capture environmental crimes outside of the context of war, its jurisdiction would have to be broadened. In this vein, some commentators have suggested making it a crime recklessly or intentionally to harm the environment. ${ }^{75}$ This could permit the behavior of armed forces not engaged in hostilities to be regulated, together with corporations and governments who may implement policies which promote insecurity through en rironmental modification. This crime has been named "geocide" or "ecocide." Literally, this constitutes the environmental counterpart of genocide - a killing of the earth. The logic of ecocide is as

69. IRIN News Update (March 18, 1999). The countries are: Democratic Republic of Congo, Kenya, Lesotho, Tanzania, Uganda and Zambia. The headquarters of the African Interpol will be in Nairobi, Kenya. Negotiators indicated that the arrangement was required owing to the need for international cooperation to fight wildlife crimes successfully." Id.

70. Council of Europe, Convention on the Protection of the Environment Through Criminal Law, ETS No. 172 (November 4, 1998).

71. Id. at pmbl.

72. Id. at arts. 2, 3.

73. Id. at art. 2.

74. Id.

75. This crime would operate within and outside the context of war. See, e.g., Richard A. Falk, Environmental Disruption by Military Means and International Law, in ENVIRONMENTAL WARFARE: A TeChNICAL, Legal and Policy APPRAISAL 33-51 (1984); Jesica E. Seacor, Environmental Terrorism: Lessons from the Oil Fires of Kuwait, 10 AM. U. J. INT'L L. \& POL'Y 481 (1994); Mark Allan Gray, The International Crime of Ecocide, 26 CAL. W. INT'L L.J. 215 (1996); Berat, supra note 48; Caggiano, supra note 57; Yuzon, supra note 26. 
follows: significantly harming the natural environment constitutes a breach of a duty of care, and this breach consists, in the least, in tortuous or delictual conduct and, when undertaken with willfulness, recklessness or negligence, ought to constitute a crime. ${ }^{76}$

Although some international environmental lawyers may find the criminalization of ecocide to be intellectually attractive, it seems fair to say that its chances of being negotiated into the jurisdiction of the ICC are slim at best. And yet environmental crimes outside armed conflict do occur and, when they do, certainly inflict "widespread, long-term, and severe" damage to the natural environment. Examples of such crimes could include reckless misconduct at nuclear power facilities, ${ }^{77}$ testing of biological weapons, or intentional dumping of oil and chemical wastes from ships (often cruise ships) at sea. ${ }^{78}$ Trade in endangered species, hazardous wastes and ozone-depleting substances constitutes an underground market estimated at \$U.S. 20 billion annually. ${ }^{79}$ Another particularly troubling example of what is arguably an environmental crime which is essentially unregulated at the international level notwithstanding its transnational effects is the setting of forest fires in the Amazon basin and in Indonesia. In both cases, there is compelling evidence that these fires had been deliberately set by businesses seeking to clear the forests for economic development. ${ }^{80}$

76. See Mark A. Drumbl, Waging War Against the World: The Need to Move From War Crimes to Environmental Crimes, 22 FORDHAM INT'L L.J. 122, 142 (1998).

77. A case in point could be the $\mathbf{1 9 8 6}$ meltdown at the Chernobyl plant in the former Soviet Union. See Berat, supra note 48 , at 345 (There is substantial evidence that although Soviet scientists and governmental officials were aware that the Soviet nuclear power plant design was flawed and had the potential for causing unmitigated disaster, they persisted in maintaining old plants and built new ones without design modification.).

78. See Douglas Frantz, Sovereign Islands: Gaps in Sea Laws Shield Pollution by Cruise Lines, N.Y. TIMES, January 3, 1999, at Al. (documenting pollution activities by the Royal Caribbean Cruise Lines, proof of which induced United States courts to order a $\$ 9$ miltion fine and a promise that the dumping practices would cease); See Matthew L. Wald, Cruise Line Pleads Guilty to Dumping of Chemicals, N.Y. TIMES, July 22, 1999, (documenting further pollution activity by Royal Caribbean after the original fine, which lead to a guilty plea to an additional $\$ 18$ million fine). Although United States authorities were ultimately successful in asserting jurisdiction over the cruise ships and subjecting them to United States law, this was not an easy process. "The ships fly foreign flags and the parent companies are registered in foreign countries, often putting them outside the reach of the authorities in this country." See Wald, supra note 79.

79. Eight Countries Agree to Fight Environmental Crime, N.Y. TMES, April 6, 1998, at A4.

80. John Klotz, 20:12 National L.J., (November 17, 1997) at A18 (col. 3). For the Indonesian context alone, see Randy Lee Loftis, The Tropics Are on Fire, TORONTO STAR, June 6, 1998, at C6 ("evidence shows that settlers were being paid by large corporations to burn forests to convert land into corporate-owned palm or rice plantations"). "The Indonesian Environmental Forum estimates that at least two million hectares of forests and other land were burned in 1997." See ORAN R. YOUNC, INSTTTUTIONAL Dimensions of Global Environmental Change: SCIENCE Plan 31 (1999). The effects on the environment are clear: immediate destruction, an inability of ecosystem regeneration, as well as contribution to global warming. In the end, this destruction comes full circle to affect humanity: through death and 
Nonetheless, even if negotiators had the willingness and succeeded in according the ICC jurisdiction over ecocide as a "most serious crime[ ] of concern to the international community as a whole," as to the ICC's effectiveness in terms of being able or suited to enforce such a prohibition. As a result, collapsing environmental crimes within the ICC might not be the most effective way to sanction such crimes. This Article identifies five reasons why this might be so: (1) environmental crimes may become lost amid the hurly-burly of the ICC's activities; (2) ICC personnel may have low environmental expertise and there may consequently be very high transaction costs involved in "getting up to speed" on environmental issues; (3) the sanctions which the ICC can order are not appropriate to correcting environmental desecration; (4) there is limited scope under the Rome Statute to integrate preexisting international law in the area of environmental crimes; and (5) environmental harm may well be best deterred by a negligence standard which is essentially incompatible with the mandate of a permanent international court designed to punish the most serious crimes of concern to humanity. This Article will now consider each of these in turn.

\section{A. Environmental Concerns Lost in the Shuffle}

Clearly, one of the major successes of the Rome Statute is that it creates an institution to actually punish the conduct it prohibits. Nonetheless, from the environmental point of view, the extent to which "environmental crimes" will receive the ICC's attention is uncertain given the broad array of other crimes to which it will have to direct its energies. The environmental war crime constitutes only one provision out of dozens in Part 2 of the Rome Statute. And $A[t]$ his provision has largely escaped notice amid the larger debate about the creation of the court and the scope of its jurisdiction."82 Article 8(2)(b)(iv) remains peripheral to the ongoing discussions of the Working Group on the Elements of Crimes held at the Preparatory Commission sessions. ${ }^{83}$ As a result, there is no indication that, as work on the establishment of the ICC progresses, the environmental war crime will be able to attract the attention it requires in order to be effectively implemented.

disability owing to the effects of asthma and smog-related illnesses, and, in the case of the Indonesian fires, creating smoke and haze which may have induced a plane crash in Sumatra which took the lives of 234 people. See Loftis, supra note 81.

81. Rome Statute, supra note 1, at art. 5(1).

82. Austin and Bruch, supra note 15, at 32.

83. See Preparatory Commission for the International Criminal Court, Second Session, supra note 49; See also supra note 54. 


\section{B. Low Environmental Expertise of the Judges and Prosecutors}

Judges and prosecutors on the ICC will likely not have expertise in the area of environmental law, policy or science. This can heighten the transaction costs of proceeding judicially, ${ }^{84}$ as well as produce ineffective jurisprudence. Were environmental crimes to be litigated in a separate forum or before a specialized agency, there could be a greater guarantee of some level of scientific expertise.

\section{Inappropriate Sanctions}

Part 7 of the Rome Statute offers the most contemporary compilation of the international community's thinking on how international crimes ought to be punished. The punishment provisions of the Rome Statute contain two limitations on the effectiveness of Article 8(2)(b)(iv).

First, the jurisdiction of the ICC is limited to natural persons. This makes it impossible to find any institutional or state liability should it be difficult to prove that the actions of one or some individuals accounted for the environmental desecration. This is unlike the Council of Europe's Convention on the Protection of the Environment Through Criminal Law, Article 9 of which establishes jurisdiction over corporate offenders together with natural persons. ${ }^{85}$

Second, sentencing is limited to imprisonment, fines, and forfeiture of the proceeds of the crime. ${ }^{86}$ There does not appear to be much room to compel restitution, remediation of blight, establish civil liability or, simply put, to clean

84. For example, in the recent International Court of Justice's decision in Case Concerning the Gabcíkovo-Nagymaros Project (Hungary/Slovakia) (Sept. 25, 1997, No. 92 General List, <http://www.icjcij.org/idocket/ihs/ihsjudgemenVihsjudcontent.htmb), the judges had to be educated in the environmental science aspects of the dispute. Although there is much to be gained from educating lay people on environmental issues, this can involve significant time as well as financial costs. A specialized tribunal could avoid some of these. Making mention of the International Court of Justice begs the question whether it could serve as an adjudicator of environmental crimes. In the past, the International Court of Justice has had limited experience with environmental matters, although it has taken some very important decisions, such as the Nuclear Tests Cases (Australia v. France) 1974 I.C.J. 253; Military and Paramilitary Activities In and Against Nicaragua (Nicaragua v. United States) 1986 I.C.J. 16; and most recently in Fisheries Jurisdiction Case (Spain v. Canada) (Dec. 4, 1998). It has also recently created an Environmental Chamber with a view to playing a more proactive role in resolving environmental disputes. Nonetheless, the impediments to the effectiveness of the International Court of Justice to adjudicating environmental crimes are significant: (1) the requirement that both litigants consent to the jurisdiction of the court, which is impractical in any criminal context where it is inexorable that one litigant will unwillingly be dragged into court; and (2) there is simply no jurisdiction to hear disputes involving individuals or non-natural legal persons.

85. Council of Europe, Convention on the Protection of the Environment Through Criminal Law, supra note 71.

86. Rome Statute, supra note 1, at art. 77. 
up the environmental harm. This is again unlike the Council of Europe's Convention on the Protection of the Environment Through Criminal Law, Article 6 of which provides that sanctions include imprisonment, fines, as well as reinstatement of the environment. ${ }^{87}$ This is also unlike the UNCC's approach to remedying environmental crimes committed during the Gulf War. ${ }^{88}$ Nor does the ICC have injunctive powers to stop violations from occurring.

Without the ICC being able to order restorative or injunctive remedies, the curative nature of the punishment for causing "widespread, long-term, and severe" damage to the natural environment is limited at best. It is true that the Rome Statute permits fines and assets collected to be transferred to a Trust Fund for the benefit of victims of the crime. ${ }^{89}$ Access to this Trust Fund is provided for in Article 75, which permits the ICC to make an order specifying reparations to victims for purposes of restitution, compensation, and rehabilitation. However, the Trust Fund does not address a situation where it is the natural environment directly, and humanity only indirectly, which bears the burden of the damage. In addition, the magnitude of wartime environmental harm may be so vast that resources transferred from individual defendants simply cannot go very far in terms of remedying that harm. By way of example, in the Gulf War alone Kuwait's environmental claims filed with the UNCC total over $\$ 15$ billion. ${ }^{90}$ Another concern is that "to the extent that charges of environmental war crimes are ancillary to other serious charges, the concern for using the trust fund to aid human victims doubtless will take priority over addressing environmental harms." 91 This, once again, returns us to the problem of pursuing environmental goals in a regime principally designed to address genocide, persecution, and murder.

As a result, there is cause for concern that environmental crimes will not only be poorly cognizable under the ICC, but also that the punishment for wrongdoing will not address the unique nature of these crimes.

87. Council of Europe, Convention on the Protection of the Environment Through Criminal Law, supra note 71.

88. See supra note 14 . The UNCC is only beginning to tum to the environmental claims which have been filed. Nonetheless, initial decisions by the UNCC in other areas may reveal limitations on its effectiveness to assess compensation for environmental harms. For example, in its decision on contractual claims issued on July 1, 1998, the UNCC limited many of the asserted losses on the basis that the claimants had not established a sufficiently direct causal link to Iraqi aggression: more particularly, the UNCC required "specific proof that the failure to perform was the direct result of Iraq's invasion and occupation of Kuwait." See Austin and Bruch, supra note 15 , at 32,35 . In the end, the contractual claimants received less than onetenth of the damages they had asserted. $I d$. at 32 . Rigorous requirements of causality and directness of damage may make it difficult for environmental and public health claims to succeed.

89. Rome Statute, supra note 1, at art. 79.

90. Austin and Bruch, supra note 15, at 33.

91. Id. at 39 . 


\section{Limited Scope of Judicial Interpretation}

The list of enumerated war crimes under Article 8(2)(b) appears to be exhaustive. After all, the use of the term "namely" implies that the ICC is not to have jurisdiction over serious violations of the laws and customs of war which are not listed in Article $8(2)(b)$. There is thus little opportunity for judicial interpretation to reach beyond the enumerated environmental war crime. To this end, it might be difficult for the ICC to use Article $21^{92}$ to incorporate in its jurisdiction the very small number of international legal materials which may provide more proactive sanction of environmental war crimes than that found in Article 8(2)(b)(iv). ${ }^{93}$ This constitutes further evi-

92. Rome Statute, supra note 1, at art. 21(1), which states that the Court shall apply: (a) In the first place, this Statute, Elements of Crimes and its Rules of Procedure and Evidence; (b) In the second place, where appropriate, applicable treaties and the principles and rules of international law, including the established principles of the international law of armed conflict.

93. In addition to the ENMOD Convention and Protocol I, these fragments include the International Law Commission Draft Articles on State Responsibility (provides that an intemational crime may result from, inter alia, a serious breach of an international obligation of essential importance for the safe-guarding and preservation of the human environment, such as those prohibiting massive pollution of the atmosphere or of the seas). See INTERNATIONAL LAW COMMISSION's DRAFT ARTICLES ON STATE RESPONSIBLITY, art. 19(3)(d) (Shabtai Rosenne ed., 1991). This is one of the few international legal documents prior to the Rome Statute which demonstrated a willingness to criminalize environmental degradation. The International Law Commission Draft Code of Crimes Against the Peace and Security of Mankind recognizes as "war crimes:" (i) extensive destruction ... of property, not justified by military necessity and carried out unlawfully and wantonly; (ii) employment of poisonous weapons or other weapons calculated to cause unnecessary suffering: (iii) wanton destruction of cities, towns or villages, or devastation not justified by military necessity; and (iv) in the case of armed conflict, using methods or means of warfare not justified by military necessity with the intent to cause widespread, long-term and severe damage to the natural environment and thereby gravely prejudice the health or survival of the population and such damage occurs. See INTERNATIONAL LAW COMMISSION DRAFT CODE OF CRIMES AGAINST THE PEACE AND SECURITY OF MANKIND, art. 20, G.A. Res. 97, U.N. GAOR, 33d Sess., Supp. No. 45, at 220, U.N. Doc. A/33/45 (1978); amended by G.A. Res. 151, U.N. GAOR, 42d sess., Supp. No. 49, at 292, U.N. Doc. A/42/49 (1987). Some of these crimes were incorporated into the Rome Statute. See, e.g., Rome Statute, supra note 1, at arts. 8(2)(a)(iv), 8(2)(b)(xvii), 8(2)(b)(xviii), 8(2)(b)(xx). The 1907 Hague Regulations deem it prohibited to destroy or seize the enemy's property, unless such destruction or seizure be imperatively demanded by the necessities of war. See Regulations Respecting the Laws and Customs of War on Land, annexed to the Convention Respecting the Laws and Customs of War on Land, art. 23(g), Oct. 18, 1907, 36 Stat. 2277. Although not explicitly mentioned, the natural environment can be considered to constitute "property;" however, it is unclear whether the natural environment within the global commons would fall within the notion of "property" since it is neither privately nor nationally owned. For a review of other internationally negotiated provisions which might provide ancillary protection to the environment during wartime, see Richards and Schmitt, supra note 7, at 1067-73. There are also some soft law agreements which may inform the content of international standards. See World Charter for Nature, G.A. Res. 377 U.N. GAOR, 37th Sess., 48th plen. mtg. (1982), Principle 5 ("Nature shall be secured against degradation caused by warfare or other hostile activities."). See also Rio Declaration on Environment and Development, UN Doc. ACCONF.151/5Rev.1, reprinted in 31 I.L.M. 874 (1992), Principle 24 ("Warfare is inherently destructive of sustainable development. States shall therefore respect international law providing protection for the environment in times of armed conflict and 
dence of the limited ability of the ICC to accommodate environmental protection concerns. After all, without the flexibility to go beyond the words of the Rome Statute notwithstanding developments in international environmental law, the ICC may not be able to do justice to any such developments.

\section{E. No Room for Negligence or Recklessness}

The ICC is designed to deter criminal behavior. Unlike direct humanitarian abuses, environmental crimes during warfare may often involve conduct which tends more to the negligent, reckless, or willfully blind than to the intentional. Intention is always difficult to prove. So, too, is causation. Consequently, in order for the ICC to remain within its present mandate it will have to let go all but the most flagrant incidents of deliberate environmental desecration.

As a result, some of the recommendations suggested in this Article to enhance the effectiveness of Article 8(2)(b)(iv) may simply not be able to be accommodated by the present mandate of the ICC. ${ }^{94}$ Two commentators have offered the following well-placed remarks regarding two of these recommendations:

[I] $t$ is difficult to imagine how the [ICC] could relax both the threshold of damage and the intent requirement while remaining within its existing mandate. The countries that acceded to the Rome Statute simply could not have intended to let their military officers be prosecuted for any action, committed with any state of mind, that causes any environmental damage. 95

If only the most egregious form of environmental insecurity has been caught by the ICC, does this augur well for the future promotion of environmental security within the structures of international criminal or humanitarian law? In the end, these structures may only be able to address environmental insecurity in a very limited fashion. The question thus arises

cooperate in its further development, as necessary."). See also U.N. General Assembly Resolution on the Protection of the Environment in Times of Armed Conflict, G.A. Res. $47 / 37$ (November 25, 1992) (environmental considerations constitute one of the elements to be taken into account in the implementation of the principles of the law applicable in armed conflict). The International Court of Justice has ruled that states "must take environmental considerations into account when assessing what is necessary and proportionate in the pursuit of legitimate military objectives." See International Court of Justice, Legality of the threat or use of nuclear weapons, Advisory Opinion (July 8, 1996), at 30.

94. See also Drumbl, supra note 77, at 129-30, 133 (provides a more detailed discussion of these recommendations).

95. Austin and Bruch, supra note 15, at 39. 
whether encouraging remediation as a "punishment" (instead of individual imprisonment; fines, and the resultant stigmatization) might bring more nations on board in terms of sanctioning less egregious (yet, when aggregated, likely more destructive) forms of environmental destruction during armed conflict. If so, then an organization supervising a strict liability regime supplemented by a remediation fund might be a preferable institutional device. Such an organization could be established on a regional or ad hoc basis (such as the UNCC). On the other hand, such an institution may be capable of development as a permanent multilateral entity which could minister to the remediation of global environmental harm. If the fund were to operate on an "at-fault" basis, then it could be financed by the international community yet retain subrogation rights against perpetrators of environmental harm. If the remediation fund were to operate on a "no-fault" basis, it could be capitalized by international contributions assessed by the size and nature of a nation's armed forces (reflecting the capacity of those forces to create environmental harms). ${ }^{96}$

Capitalization can also be sought from the private sector, namely manufacturers of weapons. In this latter regard, the International Fund for the Compensation for Oil Pollution Damage can serve as a precedent, as it is in part capitalized by "fees imposed on oil transported on the high seas, and supplemented by contributions from tanker owners, oil producers, refiners, and marketers."97 In the least, such funds can assist immediate mitigation efforts which will usually reduce the long-term costs of remediation. In this latter regard, Austin and Bruch recommend the creation of an "emergency response task force" which would be financed by the fund and could spearhead initial mitigation efforts. ${ }^{98}$

\section{Punitive Sanction, Proactive Protection, or} ENVIRONMENTAL JUSTICE?

A more fundamental question lurks beneath any evaluation of the ICC as a mechanism to promote environmental security. Essentially, the ICC represents a punitive, retributive justice paradigm in which certain serious crimes against the international community are to be redressed through the prosecution and imprisonment of selected individuals. The foundational question for international environmental lawyers is whether a punitive methodology will actually promote environmental security.

96. Id. at 41 .

97. Environmental funds in the United States have also been proffered as potential precedents. These include Superfund, the Oil Spill Liability Trust Fund, the Abandoned Mine Reclamation Fund, the Leaking Underground Storage Tank Trust Fund, and the Black Lung Disability Trust Fund. Id.

98. Id. at 42 . 
It is clear that considerable symbolic and precedential value can emerge from the criminal punishment of invidious perpetrators of intentional environmental desecration. However, what about the practical effect? Cases of intentional environmental destruction do not, when aggregated, constitute the most significant source of harm to the environment. Since the ICC can only capture the intentional infliction of environmental harm, it leaves undeterred the activities which cause the greatest amount of environmental harm - negligent or reckless conduct. As a result, the question arises whether a greater level of deterrence can be achieved through preventative measures as opposed to the threat of criminal punishment. This is a question that environmental advocates at the domestic level have long considered. At the domestic level, there has been much discussion regarding the limits of punitive ex post punishment as a device to promote environmentally respectful behavior. Many advocates prefer a focus on including as policy devices incentive-based regulation and proactive ex ante prevention. Is there any reason why such a methodology might not prove beneficial at the international level?

Implementing this second approach - proactive protection - will entail linkages beyond the legal context. Examples include the creation of economic disincentives to producing environmentally destructive weaponry, technology transfers to assist developing countries to pursue national security interests in more of an environmentally friendly manner, and financial assistance mechanisms, for example for the safe decommissioning of nuclear weapons. Linkages to trade and investment should be developed so as to create disincentives to export and sell the more environmentally injurious military technology. One final linkage which is of considerable importance involves international peace-keeping or peace-enforcement forces. These could be mandated to ensure environmental, along with humanitarian, protection. Allotting these international forces a "green-keeping" mandate could help integrate international environmental norms into internecine conflict. By way of example, were United Nations involvement in Somalia to have had a "greenkeeping" mandate, then practices of deforestation and assaults on water purity which were commonplace in the conflict - could have been much better addressed. Ultimately, the prevention of environmental crime cannot be disaggregated from the fact that environmental scarcity and resource depletion are often the cause of military conflict. ${ }^{99}$ As a result, equipping nations (through technology transfers, transparency of information or financial

99. By way of example, the Rwandan conflict was partly precipitated by demand for arable land. Over the past three decades, average farm size has declined from two hectares per family to 0.7 hectares. On the relationship between agricultural land-use and the Rwandan genocide. See Guenthar Baechler, Rwanda: The Roots of Tragedy, Battle for Elimination on an Ethno-political and Ecological Basis, in ENVIRONMENTAL DEGRADATION AS A CAUSE OF WAR, VOLUME II, 461-502 (1996). 
assistance) to engage in proper environmental management and sustainable development could have the collateral benefit of mitigating military aggression.

A relatively new wave of litigation in the United States reveals a third approach to attaining environmental security: environmental justice claims under the United States Constitution ${ }^{100}$ or under Title VI of the Civil Rights Act. ${ }^{101}$ These claims meld environmental protection and civil rights. The nub of these claims stems from the factual observation that "environmental degradation often has a distinctly racist aspect." ${ }^{102}$ More specifically:

[R]eports generally indicate that people with relatively low incomes and/or people of color are more likely to have hazardous waste treatment facilities sited in their neighborhoods than are members of the population in general. [M]embers of politically less powerful groups are exposed to greater risks from hazardous waste related problems than the overall population of the United States, and are thus disproportionately carrying certain environmental burdens of modern society. ${ }^{103}$

In response to this difficult situation, the environmental justice paradigm attempts to create "equal protection from ecological hazards for all communities." 104 Aggrieved parties have argued that the uneven distribution of environmental burdens on disempowered minority groups infringes the Equal Protection Clause. ${ }^{105}$ Others have submitted that decisions to locate environmental facilities in certain regions of the country evidence discrimination in the expenditure of federal funds. ${ }^{106}$ The argument has also been raised that Environmental Protection Agency (EPA) regulations promulgated to implement

100. U.S. CONST. amends. V, XIV 1.

101. 42 U.S.C. 2000 (d) (1994).

102. Anthony D. Taibi, Comment, Environmental Justice, Structural Theory, and Community Economic Empowerment, 9 ST. JOHN'S J. 491, 492 (1994).

103. Weintraub, supra note 4, at 568-69.

104. Lincoln L. Davies, Working Towards a Common Goal? Three Case Studies of Brownfields Redevelopment in Environmental Justice Communities, 18 STAN. ENVTL. L.J. 285, 287 (1999). "[L]owincome and minority communities bear the brunt of the industrialized world's environmental contamination and are often the last groups to receive funding for cleanups." Id. at 288.

105. U.S. ConST. Amends. V, ("In]o person shall ... be deprived of life, liberty, or property, without due process of law;") XIV $\$ 1$ (applies to discriminatory actions taken by the states).

106. Civil Rights Act of 1964, Title VI, 42 U.S.C. $\$ 2000$ (d), 601 ("No person in the United States shall, on the ground of race, color, or national origin be excluded from participation in, be denied the benefits of, or be subjected to discrimination under any program or activity receiving Federal financial assistance"). See also Civil Rights Act of 1964, Title VI, 42 U.S.C. \$ 2000(d)(1), 602 ("Each Federal department and agency which is empowered to extend Federal financial assistance to any program or activity ... is authorized and directed to effectuate the provisions of section 2000 (d) of this tille ... by issuing rules, regulations, or orders of general applicability."). 
Title VI provide an enforceable cause of action should the exercise of the EPA's authority to manage environmental policy subject individuals to discrimination. ${ }^{107}$

Environmental justice litigation has only had limited success. No court has found a violation of the Equal Protection Clause. ${ }^{108}$ Courts have held that Title VI prohibits intentional discrimination only. ${ }^{109}$ Intentional discrimination, as opposed to disparate impact, can be very difficult to prove in environmental justice cases. ${ }^{110}$ As for the claim alleging violation of the EPA regulation, some courts have expressed doubt as to the existence of a private right of action to enforce such a claim. ${ }^{111}$ The highest profile environmental justice case thus far, Seif v. Chester Residents Concerned for Quality Living, involved a claim brought under the EPA regulations. ${ }^{112}$ The challenge was to the issuance of a permit to construct and operate a waste treatment facility, more specifically a soil incinerator. The factual underpinnings to this dispute are typical of many environmental justice claims. Chester is a city of 42,000 inhabitants located in Delaware County, Pennsylvania. ${ }^{13}$ Although Delaware County's 500,000 residents are overwhelmingly white $(\mathbf{9 1 \%})$, Chester's population is two-thirds African-American. ${ }^{114}$ The complainants allege that five of Delaware County's waste treatment facilities are located in Chester; the remaining two facilities are located in predominantly white areas. ${ }^{115}$ The fact that the state permitted the

107. Pursuant to Civil Rights Act of 1964, Title VI, 42 U.S.C. 2000(d)(1), 602, the EPA adopted regulations which state: "A recipient shall not use criteria or methods of administering its program which have the effect if subjecting individuals to discrimination because of their race, color, national origin, or sex." See 40 C.F.R. 7.35(b). This prohibition would thus prevent intentional as well as disparate impact discrimination.

108. See Bean v. Southwestern Waste Management Corp., 482 F. Supp. 673 (S.D. Tex. 1979); Terry Properties, Inc. v. Standard Oil Co., 799 F.2d 1523 (1 l th Cir. 1986); East Bibb Twiggs Neighborhood Ass'n v. Macon-Bibb County Planning and Zoning Commission, 706 F. Supp. 880 (M.D. Ga. 1989); R.I.S.E., Inc. v. Kay, 768 F. Supp. 1144 (E.D. Va. 1991). The requirement to prove the defendant acted with discriminatory intent has been a major stumbling-block for such claims. See Alice Kaswan, Environmental Laws: Grist for the Equal Protection Mill, 70 U. CoLo. L. REv. 387, 432 (1999).

109. Guardians Ass'n v. Civil Serv. Comm'n, 463 U.S. 582 (1983); New York City Environmental Justice Alliance v. Giuliani, 50 F. Supp. $2 d 250$ (S.D.N.Y. 1999).

110. See Bradford C. Mank, Is There a Private Cause of Action Under EPA's Title VI Regulations? The Need to Empower Environmental Justice Plaintiffs, 24 COLUM. J. ENVTL. L. 1, 10-13 (1999).

111. New York City Environmental Justice Alliance v. Giuliani, supra note 110; South Bronx Coalition for Clean Air, Inc. v. Conroy, 20 F. Supp. 2d 565 (S.D.N.Y. 1998).

112. 944 F. Supp. 413 (E.D. Pa. 1996), rev'd 132 F.3d 9925 (3d Cir. 1997), vacated, No. 97-1620, 524 U.S. 974 (1998).

113. Id. at 927.

114. Id.

115. The two permits granted for white areas covered facilities with a combined waste capacity of 1,400 tons per year, whereas the five permits granted in African-American areas were for facilities with a combined waste capacity of over $2,100,000$ tons per year. Id. 
new treatment facility to be located in Chester notwithstanding this pre-existing disproportionality ${ }^{116}$ prompted residents to sue the state, alleging "environmental racism" in the administrative decisions to allocate permits. The District Court dismissed the lawsuit. ${ }^{117}$ The Third Circuit Court of Appeals reversed, finding the complainants entitled to an implicit private right of action under the EPA regulations and thus permitting the claim to proceed. ${ }^{118}$ On June 8, 1998, the United States Supreme Court gave itself its first opportunity to consider environmental justice by granting certiorari to review this dispute. ${ }^{119}$ However, on August 17, 1998, the Supreme Court dismissed its grant of certiorari, vacated the Chester Residents judgment, and remanded the case back to the Third Circuit with instructions to dismiss. ${ }^{120}$ The vacatur was based on the fact the dispute had become moot: on April 30, 1998, before the Supreme Court granted certiorari, the soil incinerator permit expired and was revoked as the applicant indicated it no longer planned to site a waste treatment facility in Chester. ${ }^{121}$ The vacatur of the Third Circuit decision in Chester Residents removes an important precedent to support environmental justice claims. However, this vacatur does not mean that the Third Circuit decision is bad law. ${ }^{122}$ The Supreme Court has not yet spoken on this issue. ${ }^{123}$ As a result, the legal future of environmental justice claims in the United States may still carry promise. ${ }^{124}$ In fact, notwithstanding the procedural hurdles inherent in having an environmental justice claim heard by a court, the possibilities of facing an environmental justice lawsuit have influenced government policy in the United

116. Id. at 415 .

117. Id.

118. Chester Residents, 132 F.3d at 925.

119. Seif, 524 U.S. 915 (1998).

120. Id. at 974 (1998).

121. Mank, supra note 111, at 50. In situations where the underlying controversy is independently removed, the normal practice of the Supreme Court is to vacate the decision under appeal. Id. at 51-2.

122. Recent decisions have affirmed the existence of a private right of action to challenge administrative regulations on the grounds of disparate impact. See, e.g., Powell v. Ridge, 1999 U.S. App. LEXIS 20092 (3rd Cir. 1999); Burton v. City of Belle Glade, 178 F.3d 1175 (11 th Cir. 1999); Sandoval v. Hagan, 7 F.Supp.2d 1234 (M.D. Ala. 1998).

123. One commentator has suggested that "[t]he Supreme Court seems likely to decide this vital issue." See Mank, supra note 111, at 6 . Nonetheless, "environmental justice plaintiffs may not rely on the [Chester Residents] decision as precedent in the Third Circuit or even cite it as a valid judgment in other circuits." Id. at 51.

124. However, a recent decision of the Fourth Circuit Court of Appeals may dampen this promise. See Goshen Road Environmental Action Team v. United States Department of Agriculture, 1999 WL 187264 (4th Cir. 1999) (siting a wastewater treatment facility in a predominantly African-American neighborhood did not violate environmental justice policy concerns). 
States. ${ }^{125}$ Concerns over lawsuits and fears regarding their perceived effects have also affected the practice of environmental management. ${ }^{126}$

Might the fertile basis of internationally-negotiated anti-discrimination and human rights conventions not provide solid ground for environmental justice claims? Prohibitions against discrimination are found in the Universal Declaration of Human Rights, ${ }^{127}$ the International Covenant on Civil and Political Rights, ${ }^{128}$ and the International Convention on All Forms of Racial Discrimination. ${ }^{129}$ Important regional agreements prohibiting discrimination are found in the European Convention for the Protection of Human Rights and Fundamental Freedoms ${ }^{130}$ as well as the American Convention on Human Rights. ${ }^{131}$

125. See Exec. Order No. 12,898, 59 Fed. Reg. 7629 (1994). The Order provides that "each Federal agency shall make achieving environmental justice part of its mission by identifying and addressing ... disproportionately high and adverse human health or environmental effects of its programs, policies, and activities on minority populations and low-income populations in the United States." Id. Agencies are required to conduct programs which "substantially affect human health or the environment" so as not to "subject[ ] persons to discrimination because of their race, color, or national origin." Id. However, the Order states that it is not intended to create a right of judicial review against the United States. Id.

126. By way of example, a "broad" civil rights investigation has been launched in response to claims that the concentration of dozens of garbage transfer stations in the South Bronx discriminates against minority residents. See Paul Zielbauer, Garbage Transfer Stations Face Civil Rights Inquiry, N.Y. TMMES (March 7, 1999) at A1. More specifically, the investigation will "seek to determine whether dozens of garbage transfer stations, and the hundreds of trucks that feed them, have spawned widespread respiratory and other health problems that violate the civil rights of South Bronx residents, the vast majority of whom [n.b. 95\%] are black or Hispanic." Id. Similar investigations had previously been initiated in Michigan and Louisiana. Id.

127. Universal Declaration of Human Rights, U.N. G.A. Res. 217 (Dec. 10, 1948), art. 7 ("All are equal before the law and are entitled without any discrimination to equal protection of the law. All are entitled to equal protection against any discrimination in violation of this declaration and against any incitement to such discrimination.").

128. International Covenant on Civil and Political Rights, 999 U.N.T.S. 171 (Dec. 16, 1966), art. 2 ("Each State Party ... undertakes to respect and to ensure to all individuals within its territory and subject to its jurisdiction the rights recognized in the present Covenant, without distinction of any kind, such as race, color, sex, language, religion, political or other opinion, national or social origin, property, birth or other status."), art. 26 ("All persons are equal before the law and are entitled without any discrimination to the equal protection of the law. In this respect, the law shall prohibit any discrimination and guarantee to all persons equal and effective protection against discrimination on any ground such as race, color, sex, language, religion, political or other opinion, national or social origin, property, birth or other status.").

129. International Convention on the Elimination of All Forms of Racial Discrimination, 5 I.L.M. 352 (1966), at arts. 2, 5 (State Parties guarantee the right of everyone, without distinction as to race, color, or national or ethnic origin, to equality before the law ... in the enjoyment of the right to public health).

130. European Convention for the Protection of Human Rights and Fundamental Freedoms, 312 U.N.T.S. 221, as amended (Nov. 4, 1950), art. 14 ('The enjoyment of the rights and freedoms set forth in this Convention shall be secured without discrimination on any ground such as sex, race, colour, language, religion, political or other opinion, national or social origin, association with a national minority, property, birth or other status.").

131. American Convention on Human Rights, 9 I.L.M. 673 (November 22, 1969), art. 24 ("All persons are equal before the law. Consequently, they are entitled, without discrimination, to equal protection of the law."). 
Notwithstanding the fact these conventions may permit international environmental justice claims, thus far there has been very little literature exploring the use of international human rights as a device to propound environmental security. This is unfortunate since internationalizing environmental justice recognizes that "environmental security may be ... a global idea, only fully achievable as part of a universalization of environmental responsibility."132 For international lawyers, environmental justice may be attractive in two types of situations: (1) the equal treatment of individuals within a state; and (2) the equal treatment of individuals between states.

First, environmental justice can help combat "environmental cleansing" the deliberate misuse of the natural environment as a tool to promote the politics of racial, ethnic, or class hegemony within a nation-state. ${ }^{133}$ Environmental cleansing can deny individuals, groups and communities the "minimum quality of environment"134 needed to sustain ways of living or even lives and, as such, further political goals such as forced relocation, subjugation, assimilation, or internal colonialism. In this regard, the creation of environmental insecurity may well "reflect the governing body's discriminatory use of power." 135 When the courts and legislatures of the nation-state in question offer no recourse, individually enforceable remedies under international conventions

132. Weintraub, supra note 4 , at 564 .

133. See, e.g., Bill Weinberg, WAR ON THE LAND: ECOLOGY AND POLTICS IN CENTRAL AMERICA 76 (1991) ("IIn Nicaragua] the rainforest was destroyed by campesinos who had been pushed from their land to make way for the ecologically disastrous cotton industry, which relied heavily on pesticides and other inputs. While all Central American countries became a dumping ground' for dangerous pesticides, which are either restricted or banned in the countries where they are produced, Nicaragua also became a testing ground for new experimental pesticides with the Nicaraguan citizenry serving as the guinea-pig" [emphasis in original]). See also id. at 93; Ricardo A. Navarro, Environmental lmpacts of the Civil War in El Salvador, in PROCEEDINGS OF THE FIRST INTERNATIONAL CONFERENCE ON ADDRESSING ENVIRONMENTAL CONSEQUENCES OF WAR: LegAL, ECONOMIC AND SCIENTIFIC PERSPECTIVES (June 10-12, 1998); Bernard Q. Nietschmann, The Effects of War and Peace on Nicaragua's Environments, in PROCEEDINGS OF THE FIRST INTERNATIONAL CONFERENCE ON ADDRESSING ENVIRONMENTAL CONSEQUENCES OF WAR: LEGAL, ECONOMIC AND SCIENTIFIC PERSPECTIVES (June 10-12, 1998) ("barrels of cyanide from gold mines were dumped in rivers to kill fish eaten by rebel supporters"); Alvaro José Rodriguez, Environmental Impacts of the Internal Armed Conflict in Colombia, in PROCEEDINGS OF THE FIRST INTERNATIONAL CONFERENCE ON ADDRESSING ENVIRONMENTAL CONSEQUENCES OF WAR: LEGAL, ECONOMIC AND SCIENTIFIC PERSPECTIVES (June 10-12, 1998) (discussing fumigation of agricultural lands where coca is allegedly grown, obliging peasants to move into and clear-cut formerly pristine rainforest in order to cultivate subsistence crops). See also supra, note 36 (on Colombia).

134. See Weintraub, supra note 4, at 542-53. The notion of environmental cleansing recognizes how behavior directed against the environment can readily constitute a threat to the security of people, demonstrating "the increasingly important role that environmental management plays in modern political relationships." See id. at 536.

135. Id. at 564. 
or political pressure applied internationally may constitute the best available options to redress the wrongs.

Second, environmental justice can address situations in which developing countries and people of color disproportionately bear the environmental externalities of the world's industrialization. One important example is the export of hazardous waste from the developed world, where it is produced, to the developing world, where it is to be disposed. ${ }^{136}$ Although developing countries may be paid to receive these wastes (often quite generously), they often lack the technology to safely and adequately dispose of them upon receipt; they may also lack the regulatory and scientific infrastructure to supervise such disposal. ${ }^{137}$ This then creates profound environmental insecurity in local communities. One commentator has argued that "the shipment of hazardous waste from developed to developing countries is environmental racism on an international scale." 138 Although certain recently negotiated conventions ${ }^{139}$ provide disincentives to and in some cases even prohibit the shipment of certain wastes from developed countries to developing countries, the characterization of these shipments as infringing environmental justice allows nations not signatories to these agreements to be held to similar standards. Embedding the prohibition against such shipments in the discourse

136. See, e.g., Rozelia S. Park, An Examination of International Environmental Racism Through the Lens of Transboundary Movement of Hazardous Wastes, 5 IND. J. GLOBAL LEGAL STUD. 659 (1998); Hugh J. Marbury, Hazardous Waste Exportation: The Global Manifestation of Environmental Racism, 28 VAND. J. TRANSNAT'L L. 251 (1995).

137. See Park, supra note 137, at 668-70. As a result, the cost of disposal in these developing countries for the polluter is much lower than it would be were the disposal to occur in a developed country. See id. ("In 1989, in Africa, waste disposal costs were about forty dollars per ton. In contrast, the cost was four to twenty-five times this amount in Europe and in the United States, twelve to thirty-six times greater."). See also Marbury, supra note 137, at 257.58, 260 ("Given developing nations' inexperience in handling hazardous waste and the large quantities of such waste generated each year, the possibility of a major environmental disaster exists.").

138. Park, supra note 137, at 660 . See also Marbury, supra note 137, at 291 ("Hazardous waste exporting is just environmental racism on a global scale. The main similarity between the two is who shoulders the burden of living near and with the hazardous waste. Under each regime, the poor are forced to shoulder a disproportionate amount of national and global burdens.").

139. Basel Convention on the Control of Transboundary Movements of Hazardous Wastes and Their Disposal, March 22, 1989, 28 I.L.M. 657 (1989), amended by Conference Decision IV/12 (March 25, 1994), adopted by the Third Meeting of the Conference of the Parties to the Basel Convention, U.N. Environmental Programme, UNEP/CHW.3/35 (1995); Bamako Convention on the Ban of the Import into Africa and the Control of Transboundary Movement of Hazardous Wastes within Africa, opened for signature Jan. 29, 1991, 30 I.L.M. 773 (1991); The Fourth African, Caribbean, and Pacific States-European Economic Community Convention of Lomé, opened for signature March 22, 1990, 29 I.L.M. 783 (1990). One problem which could be addressed by characterizing these shipments as a cognizable violation of the right to environmental security is that the various conventions have "failed to coalesce into a single, dominant solution for the externalities of hazardous waste exporting, which continue to be a vexing problem." See Marbury, supra note 137, at 262. 
of human rights also allows a broader range of exported substances to be subject to review: for example, the adverse environmental impacts caused by the export of dangerous or environmentally risky products to the developing world. Should these products not constitute "hazardous wastes," then they fall outside the scope of the international conventions. However, the distributional implications of such exports could well be caught by international antidiscrimination standards applied to the environmental context.

Elevating environmental justice to the international level will require the creation of new institutions. What tribunals, courts, or agencies can determine the existence of environmental injustice? Are domestic courts or existing international human rights commissions (for example the United Nations Commission on Human Rights) sufficient? Or will new international human rights tribunals need to be created? On a related note, elevating environmental justice to the international level will also require the establishment of new rights. For example, is there an internationally recognized right to public health or security of the person? ${ }^{140}$ Such a right must exist in order for there to be a remedy for its infringement by discriminatory environmental mismanagement or insecurity. In bridging this particular gap, advocates for environmental justice should be encouraged by the Stockholm Declaration, which as early as 1972 contemplated the linkages between justice, equality, and environmental well-being:

Man has the fundamental right to freedom, equality and adequate conditions of life, in an environment of a quality that permits a life of dignity and well-being, and he bears a solemn responsibility to protect and improve the environment for present and future generations. ${ }^{141}$

A subsidiary question which arises (and has been particularly pivotal in the United States jurisprudence) is whether the discrimination must be intentional or whether proof of discriminatory impact suffices to justify a complaint.

In sum, the opportunities for environmental justice claims as a device to promote transnational environmental security remain inchoate and unexplored. It remains, though, that environmental justice claims at the intra-state level may provide important linkages to the political right of self-determination. Such claims recognize that maintenance of a "minimum quality of the environment" is a prerequisite to the existence (and enjoyment) of civil and political rights, as well as the dignity of the individual. Environmental justice claims can also promote democratization by encouraging local and citizen group involvement

140. See Popovic, supra note 23, at 68 (discussing the right to live as broader than the traditional concept of the right to life).

141. Declaration of the United Nations Conference on the Human Environment (Stockholm Declaration), U.N. Doc. AVCONF.48/14, 11 I.L.M. 1416 (1972), Principle 1. 
in the political process. ${ }^{142}$ By "permitting individual victims to activate international enforcement procedures," these claims increase political participation together with transparency of information. ${ }^{143}$ Environmental justice claims at the macro, inter-state level may help link environmental protection with socio-economic rights, such as the right to development. Opportunities for development may be hindered when the developed world passes the costs of its industrialization onto developing nations. Ultimately, a macro, transnational conception of environmental justice can constitute a theoretical justification for the promotion of equality in the sharing the benefits and burdens of environmental management globally. As for the burdens, environmental justice may justify distributive equality in terms of shouldering the responsibilities of dealing with global environmental problems (e.g. climate change, protecting the ozone layer). True distributive equality in this regard would require the developed world to bear a considerably larger burden of assuming these costs and responsibilities. This, in turn, feeds into the discourse of "common but differentiated responsibilities" between developed and developing countries which is growing into a principle of international environmental law. ${ }^{144}$

In the end, the question is not really whether punitive sanction or proactive protection or environmental justice should constitute the dominant approach to promote environmental security. Instead, a polycentric approach blending all three paradigms might maximize policy results. Such a multifaceted approach could promote environmental security by criminally punishing the most invidious offender, dissuading the negligent offender through incentive-based schemes, cleaning up blighted communities, according individuals a medium to air grievances, and encouraging the global community to equally shoulder the environmental externalities of industrialization.

142. This has been one of the strengths of the environmental justice movement in the United States. See Taibi, supra note 103, at 491-92. ("[T] unaffiliated groups whose identity and membership largely center on a particular location or issue. These groups are led by and draw their ranks not from educated professionals but from the more typically politically alienated lower middle class."). On the international level, see Council of Europe, Convention on the Protection of the Environment Through Criminal Law, supra note 71, at art. 11 (parties may grant environmental non-governmental organizations the right to participate in criminal proceedings concerning offenses under the Convention).

143. Popovic, supra note 23, at 89 . See also id. at 88 ("A human rights mechanism would enhance the prospects for protecting the environment because it would help the international community see the environmental impact of war from the perspective of the most affected individuals and groups.").

144. See, e.g., Philippe Cullet, Differential Treatment in International Law: Towards a New Paradigm of Inter-state Relations, 10 E.J.I.L. 549, 577 (1999). 


\section{CONCLUSION}

Article 8(2)(b)(iv) of the Rome Statute criminalizes the willful infliction of "widespread, long-term and severe damage to the natural environment." The inclusion of this crime within the jurisdiction of the ICC is cause for limited celebration and some disappointment. The disappointment flows from the fact that such conduct is already "prohibited" by virtue of Protocol I and the ENMOD Convention. Nonetheless, the Rome Statute does provide a significantly more viable mechanism to sanction this illegal conduct. It will, however, be very difficult to prove "widespread, long-term, and severe damage;" proof will be rendered more problematic owing to the conjunctive nature of these terms. Additionally, the environmental war crime requires a very significant level of knowledge and intentionality. Criminal behavior is not sanctioned on an objective basis and, consequently, ignorance of the law might serve as a defense. This would be less than desirable as environmental education and transparency of knowledge would then be discouraged. The availability of military advantage as a defense to the intentional infliction of widespread, longterm and severe damage to the natural environment may further denude the practical effect of Article 8(2)(b)(iv).

The inclusion of environmental crimes within the Rome Statute should also give rise to considerable reflection. The principle point of contemplation is the usefulness of the ICC as a device to promote environmental security. Ultimately some of the foundational limitations of the ICC as a device to promote such security flow not only from its structure, but also from the punitive paradigm it embodies. As a result, this Article suggests that proactive protection and environmental justice be woven into the international legal response to environmental crimes. Proceeding with this blended approach allows environmental security to serve as a lightning-rod uniting disparate fields such as international criminal law, the law of war, international trade law, international humanitarian law, and international anti-discrimination law. Only through such a polycentric approach can environmental security be promoted outside of the narrow confines of widespread long-term and severe damage intentionally inflicted during an international armed conflict. 